\title{
Spatial impact of land use/land cover change on surface temperature distribution in Saranda Forest, Jharkhand
}

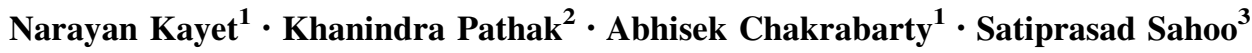

Received: 18 May 2016/ Accepted: 4 June 2016/Published online: 8 July 2016

(C) Springer International Publishing Switzerland 2016

\begin{abstract}
Land surface temperature (LST) is an important factor in global climate change studies, in estimating radiation budgets, in heat balance studies and as a control for the climate dynamics and modelling frame. This study analyses the land surface temperature distribution in the region of Gua, Chiria, Megataburu and Kiriburu. Landsat Thematic Mapper and Enhanced Thematic Mapper Plus data of the year 1994, 2004 and 2014 are used to effects of land use/land cover changes on the surface temperature distribution. The remote sensing technique is used to detect the land use changes, its impact on the land surface temperature and variation in mean LST from these hot spots. Thermal infrared remote sensing proved its capability in monitoring temperature and affecting microclimate in urban areas. Results of the study show that the LST of different land use differs significantly. This study also indicates that the external temperature has an impact on surfaces of self-heating areas. This study demonstrates that the growth of rapid mining industrial area significantly decreases the vegetation areas, hence increased the surface temperature. This analysis demonstrates the potential applicability of the methodology for climate modelling frame.
\end{abstract}

Narayan Kayet

rsrsnarayan@mail.vidyasagar.ac.in

1 Department of Remote Sensing and GIS, Vidyasagar University, Midnapore, India

2 Department of Mining Engineering, Indian Institute of Technology, Kharagpur, Kharagpur, India

3 School of Water Resources, Indian Institute of Technology, Kharagpur, Kharagpur, India
Keywords Thermal remote sensing - LULC · LST model · Change detection · GIS

\section{Introduction}

Land surface temperature is the skin temperature of earth surface phenomena. It is the feeling of how much hot the surface of the earth. It depends on the different LULC categories. LST is entirely related to the physical process of surface energy. It provides information on time to time variation of earth surface energy change. It is an important factor for monitoring vegetation, climate change, and change in the built-up area. Now a day it becomes a serious environmental issue (Sahoo et al. 2016). This is because the global temperature of the earth is increasing day by day for greenhouse gas effect. Scientist is much more concern about the LST because this enhanced temperature has the appalling impact on the global climate. Hence, the researchers in this field need to increase. Several studies have been done on the estimation of land surface temperature. Use of Landsat data for development of thermal mapping of an area was investigated by many authors and the method is now well established. Examined the use of the band six of Landsat TM data for getting thermal information (Southworth 2004). Used Landsat data for thermal studies of Singapore forest for zoning areas with different characteristics (Nichol 1995). Remote sensing and geographical information system (GIS) techniques are used to detect the land use changes and its impact on the land surface temperature (LST) (Buyadi et al. 2013). Studied, use of remote sensing for desert temperature mapping and presented a methodology for assessment of land surface temperature in the Yardang Region of Lut Desert (Iran) based on field 
measurements and Landsat Thermal Data (Alavipanah et al. 2007). Reported advanced method for improvements in land surface temperature retrieval from the Landsat series thermal band using water vapor and air temperature (Cristóbal et al. 2009). Discussed the detailed methodology they used for determining the dynamism of land use changes in surface temperature for a particular case study in Kenya (Sahoo 2013; Ragin 2014; Kayet and Pathak 2015). The heat island is an inactive dome of air above urban areas caused by heat engrossed and released by buildings, concrete structures, and other impermeable surfaces (Renssen et al. 2005). Land surface temperature (LST) forms an important climate variable related to climate change and is an indicator of the energy balance at the surface since it's a key parameter in the physics of the land surface processes (James and Mundia 2014). The LST and vegetation indices have also been collective in a scatter plot to get the Temperature-Vegetation space which reveal the chronological trajectory of pixels ranging from low temperature high vegetation conditions to high temperaureole vegetation conditions as an result of urbanization method (Amiri et al. 2009; Lim et al. 2009; Weng et al. 2004). Kato and Yamaguchi (2005) have developed a new method to separate the anthropogenically discharged heat and natural heat radiation from the sensible heat flux, based on a heat balance model using satellite remote sensing and ground meteorological data. This method was applied to ASTER and ETM+ data for the daytime during spring, summer and winter and for the nighttime during autumn in Nagoya, Japan. The spatial model of urban green space sand impervious surfaces have been deliberate using some landscape metrics similar to patch density, edge density, landscape shape index (Schwarz et al. 2011; Li et al. 2012; Mann et al. 2009; Zhou et al. 2011) and the relationship between the landscape metrics and local statistics has been done by Zheng et al. (2014). Mann et al. (2009) used a global climate proxy network to reconstruct surface temperature change patterns over the pride. The patterns of temperature change imply dynamical responses of climate to natural radiative forcing changes involving El Niño and the North Atlantic Oscillation-Arctic Oscillation. The urban heat-island result occurs as a consequence of increased sensible heat flux since the land surface to the atmosphere near towns. Sensible heat flux consists of two components, heat radiation due to solar input and heat due to anthropogenic discharge. The latter may be enhanced by changes in the usage of an artificial land surface (Kato and Yamaguchi 2005). Land surface temperature (LST) and percent surface imperviousness (SI), both derived from satellite imagery, have been used to characterize the urban heat island effect, a phenomenon in which urban areas are warmer than non-urban areas (White-Newsome et al. 2013). Surface Urban Heat Island involves the assessment of surface temperature since not the direct capacity of surface radiation, upwelling thermal radiance and surface emissivity using thermal remote sensing (Voogt and Oke 2003).

In the present study, an effort is made to identify the land surface temperature change in the study area with the help of remote sensing and Geographical Information System (GIS) based approach. Since remote sensing is a powerful tool for obtaining spatial and temporal information within a small period, this method proved itself one of the best methods for change detection study. A large deposit of Iron ore is available in that area. Mine planning operation in such a hilly terrain makes the area an important research target.

Hence, the primary focus of the study is to determine the change in land surface temperature at the present study area for three different time span. This study also emphasizes on the detection of the change in land surface temperature with the change in LULC categories, specially the mining areas.

\section{Study area}

The Saranda forest of Jharkhand is endowed with the number of rich iron ore deposits. The forest is situated in West Singhbhum district of Jharkhand. It is famous for Asia's largest Sal forests and is an important elephant habitat. The location of the forest is within latitude $22^{\circ} 00^{\prime} 45.04^{\prime \prime}-22^{\circ} 12^{\prime} 36.81^{\prime \prime} \mathrm{N}$ and longitude $85^{\circ} 08^{\prime} 18.8^{\prime \prime}-$ $85^{\circ} 24^{\prime} 37.21^{\prime \prime} \mathrm{E}$ with average elevation of $750 \mathrm{~m}$ above the mean sea level (MSL). Saranda forest is fed by two major rivers, Karo and Koina. The catchment of these rivers comprises of a drainage system with stream order up to six. Over the last few decades, in this region, many iron ore mining towns have emerged, e.g. Gua, Chiria, Megataburu and Kiriburu, shown in the location map of the study area (Fig. 1).

\section{Materials and methodology}

\section{Data used}

The three sets of remotely sensed data used for this study include: Landsat Thematic Mapper (TM) and Enhanced Thematic Mapper (ETM+) images (with path/row 140/45) acquired on Landsat-5 TM 31 May 1994, Landsat-7 TM data of 10 May 2004 and Landsat-7 ETM+ data of 1 May 2014. The detailed information regarding the data is given in Table 1. GPS Survey and photographs are taken for collecting the ground truth data in May 2014. 


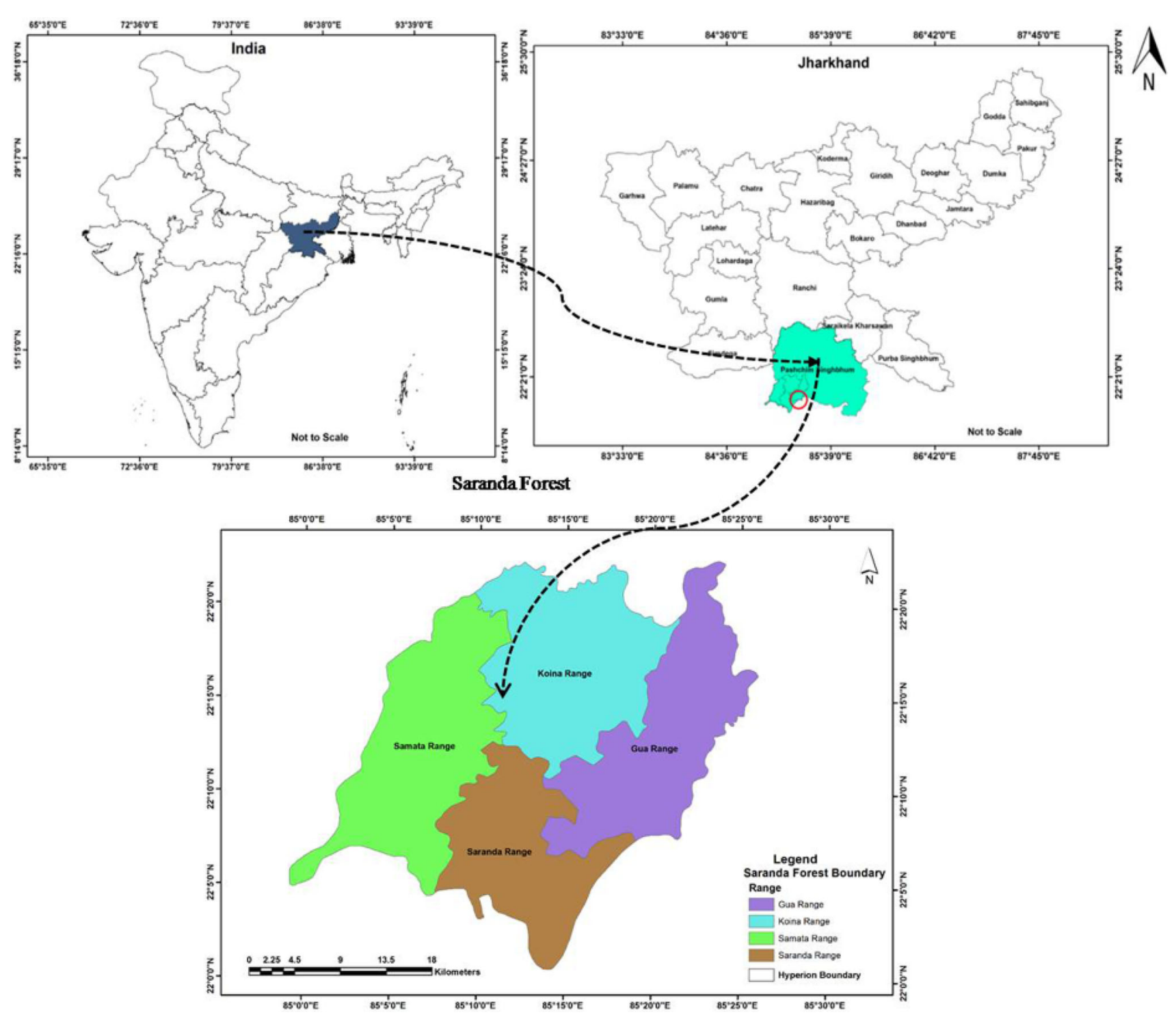

Fig. 1 Location map of the study area

\section{Land use and land cover classification}

The supervised classification method is applied to classify the land use and land cover categories. For this classification, data are collected from the field survey as well as local knowledge of the area also helped. Six training classes are defined to classify the images. The parallelepiped classification algorithm is applied for the study (Carlson and Arthur 2000). The results obtained shows a good fit with the local data. This area was classified into six classes: dense forest, open forest, agricultural land, water body wetland and built-up (mining area) using supervised classification method and maximum likelihood algorithm. The accuracy of a classification process is usually assessed by comparing the results of classification with mention data from field visits, high spatial resolution images, or top sheet (Bokaie et al. 2016).

\section{Estimation of LST}

The thermal infrared band (Landsat Band 6) records the reflectance from the earth surface for the wavelength range between 10.4 and $12.5 \mu \mathrm{m}$. In an electro magnetic spectrum, this band is referred as the thermal band. Land surface temperature plays an important role in many environmental processes. It can provide primary information on the surface physical properties and climate. For example, the TM thermal infrared data is used to observe in temperature differences between urban and rural areas in Indianapolis (Weng 2001). In most studies, LST is generated using the digital image 
processing software and following a process in GIS software. In this study, ERDAS Imagine 9.0 and ArcGIS 10.1 software are used to make the LST maps. The methodology developed for the LST mapping is given in Fig. 2.

\section{Generation of thermal map}

The Landsat Thematic Mapper (TM) and Enhanced Thematic Mapper Plus (ETM+) sensors acquire temperature

Table 1 Data used in the present study

\begin{tabular}{lllll}
\hline Different data source & Date & Resolution (m) & Path & Row \\
\hline Landsat 5TM & 31 May, 1994 & 30 & 140 & 45 \\
Landsat 7 TM & 10 May, 2004 & 30 & 140 & 45 \\
Landsat7 ETM+ & 1 May, 2014 & 30 & 140 & 45 \\
\hline
\end{tabular}

data and store this information as a digital number (DN) within a range between 0 and 255 . It is possible to convert these DNs to degrees Kelvin using a two-step process. The thermal energy responses of different landforms indicate the variations in surface temperature of different surfaces. Land surface temperatures are extracted from the thermal bands 6 and 6.1 of Landsat TM/ETM+ data.

\section{NDVI map generation}

The Normalized Difference Vegetation Index (NDVI) is a numerical indicator that uses the visible and near-infrared bands of the electromagnetic spectrum and is adopted to analyze remote sensing measurements and assess whether the target being observed contains live green vegetation. Theoretically, NDVI values are represented as a ratio
Fig. 2 Flowchart showing the methodology for LST mapping

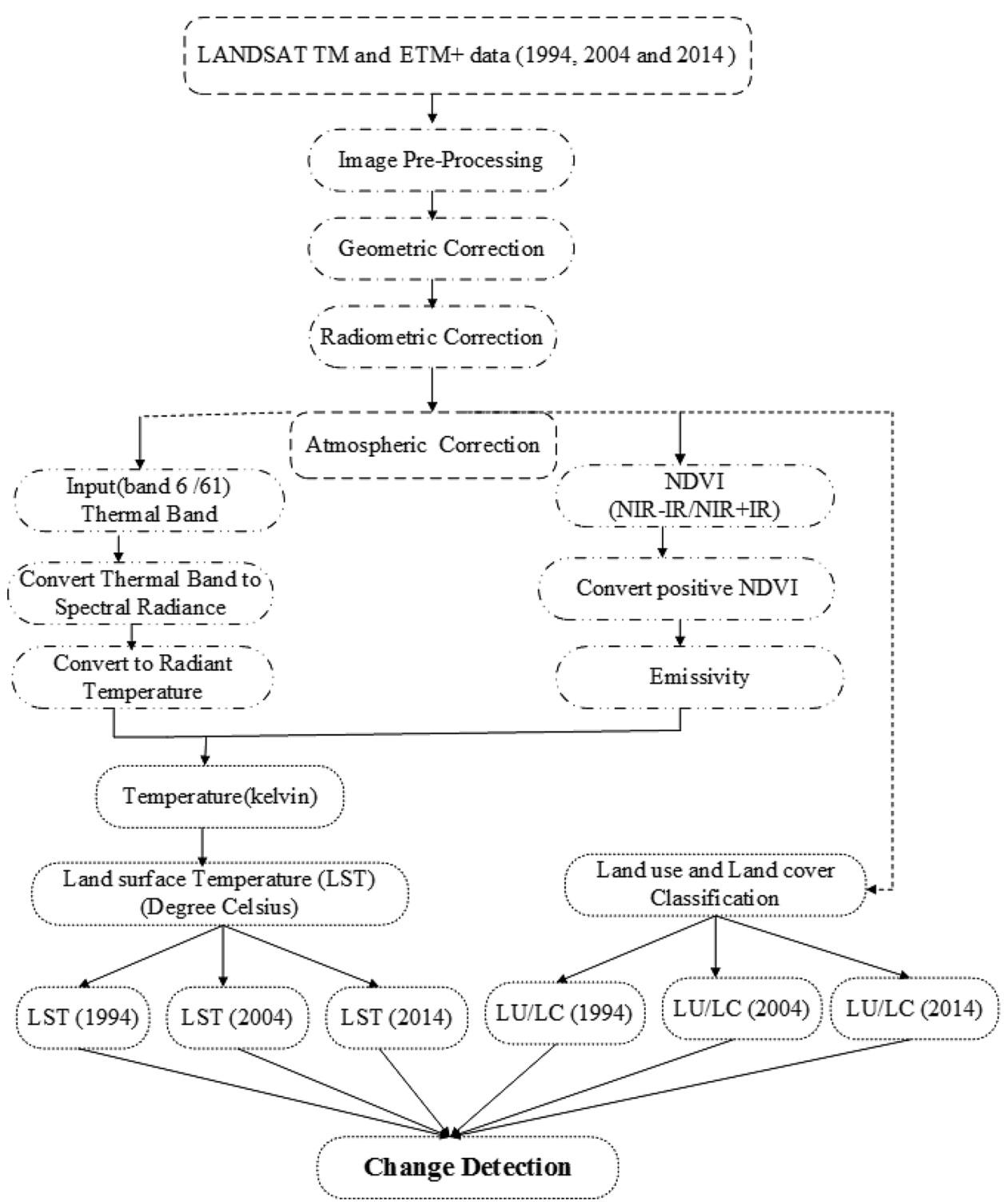


ranging in value from -1 to 1 . NDVI values can be obtained by the following Eq. 1:

$N D V I=(N I R-R E D) /(N I R+R E D)$

In equation, Band 4 defines the NIR band and Band 3 defines the RED band of electromagnetic spectrum. In this study, NDVI maps are generated in ERDAS Imagine 9.0 software.

\section{Calculation of LST}

The LST is calculated by applying the established formula. Based on Cao et al. (2008), a two-step processes are followed to derive brightness temperature from the Landsat $5 \mathrm{TM}$ Images in this study. The methodology is explained below.

1. Conversion of the digital number (DN) to spectral radiance (L) (USGS 2001) is calculated by Eq. 2.

$\mathrm{L} \lambda=\mathrm{L}_{\min }+\frac{\left(\mathrm{L}_{\max }-\mathrm{L}_{\min }\right) \times \mathrm{DN}}{255}$,

where, $\mathrm{L} \lambda$ is the spectral radiance, $\mathrm{L}_{\min }$ is the 1.238 (Spectral radiance of $\mathrm{DN}$ value 1), $\mathrm{L}_{\max }$ is the 15.600 (Spectral radiance of DN value 255), and $\mathrm{DN}$ is the digital number.

2. Conversion of spectral radiance to temperature in kelvin (USGS 2001), is calculated by Eq. 3.

$T b=k 2 / \operatorname{in}(k 1 / L \lambda)+1$,

where, $\mathrm{K} 1$ is the calibration constant 1 (607.76), $\mathrm{K} 2$ is the calibration constant 2 (1260.56), and $\mathrm{Tb}$ is the surface temperature (kelvin)

3. Calculation of NDVI

Land surface emissivity (LSE) is calculated based on NDVI values. It uses the NDVI Thresholds MethodNDVITHM by applying the following formula (Eq. 4) (Sobrino and Raissouni 2001).

$\mathrm{LSE}=1.0094+0.047 \times \operatorname{In}(\mathrm{NDVI})$

The NDVI value ranges from 0.157 to 0.727 . When the NDVI values out of the range $(0.157-0.727)$, the corresponding input LSE constant values are used.

4. Conversion of kelvin to celsius (Semenza et al. 1995) is obtained by Eq. 5 .

$T b=T b-273$.

\section{Results and discussion}

\section{Spatial distribution and changes of LST}

The application of Remote Sensing (RS) Techniques on the Thermal band information provides a tool for assessment of the Land Surface Temperature and mapping of a target area. Figure 3 show the land surface temperature maps of Saranda Forest highlighting the spatial distributions of the hot areas based on the images of 1994, 2004 and 2014. The minimum, maximum and average temperature ranges (1994, 2004, and 2014) of the area are shown in Table 2. The study reveals that the north and northwest part exhibits high temperature mainly due to built up (mining area) and wetland. Some of the high-temperature zones are also seen in the central part of the image largely due to anthropogenic land use. The overall accuracy of the classification is $78 \%$. Comparing the LST maps and the land cover classification maps, the relationship between the land cover classification and the land surface temperature can be obtained. It is evident from the map that there are four selfheating mining regions: Gua, Chiria, Megataburu and Kiriburu of the Saranda forest.

\section{Changes of LST for mining dominated region}

The result of LST for each of the mining region (Gua, Chiria, Megataburu and Kiriburu) for each study year is shown in Table 3. It is observed from the table that, in the year 1994 and 2004 the highest temperature are 32.1 and $38.07{ }^{\circ} \mathrm{C}$ respectively which is found in Gua mine region. Similarly in the year 2014, the temperature of Gua mine is most elevated $\left(42.1^{\circ} \mathrm{C}\right)$ among the others. These results show that for each study year, the highest temperature is observed for Gua mine region. This can be attributed to the largest barren area of that region. In the study area, Gua mine comprises of 393.46 ha area; Megataburu mine comprises of 128.43 ha area; Kiriburu mine comprises of 155.76 ha area, and Chiria mine consists of 86.02 ha. Hence from the result it can be said that with an increase of nonvegetated area, land surface temperature also increase. The reason behind this phenomenon is that year wise the mines area increases, which means the non-vegetated area or barren land increases. This, in turn, is responsible for the land surface temperature increase for the mines area day by day.

\section{Changes of LST for each LULC classes}

Figure 4 shows the LULC map of the study area. Table 4 shows the year wise maximum and minimum temperature for each LULC categories. Acceding to the result observed the land surface temperature changed over time depending on the different activities of different land cover and land-use categories of the study area. Error matrix is of LULC classes shown in Table 5. It can be seen accuracy assessment statistics for multiple time spans of LULC categories. It is found that the minimum and maximum temperature for builtup area year wise increases gradually. The increasing trend of LST for built-up area of Saranda forest is shown in Fig. 5. 

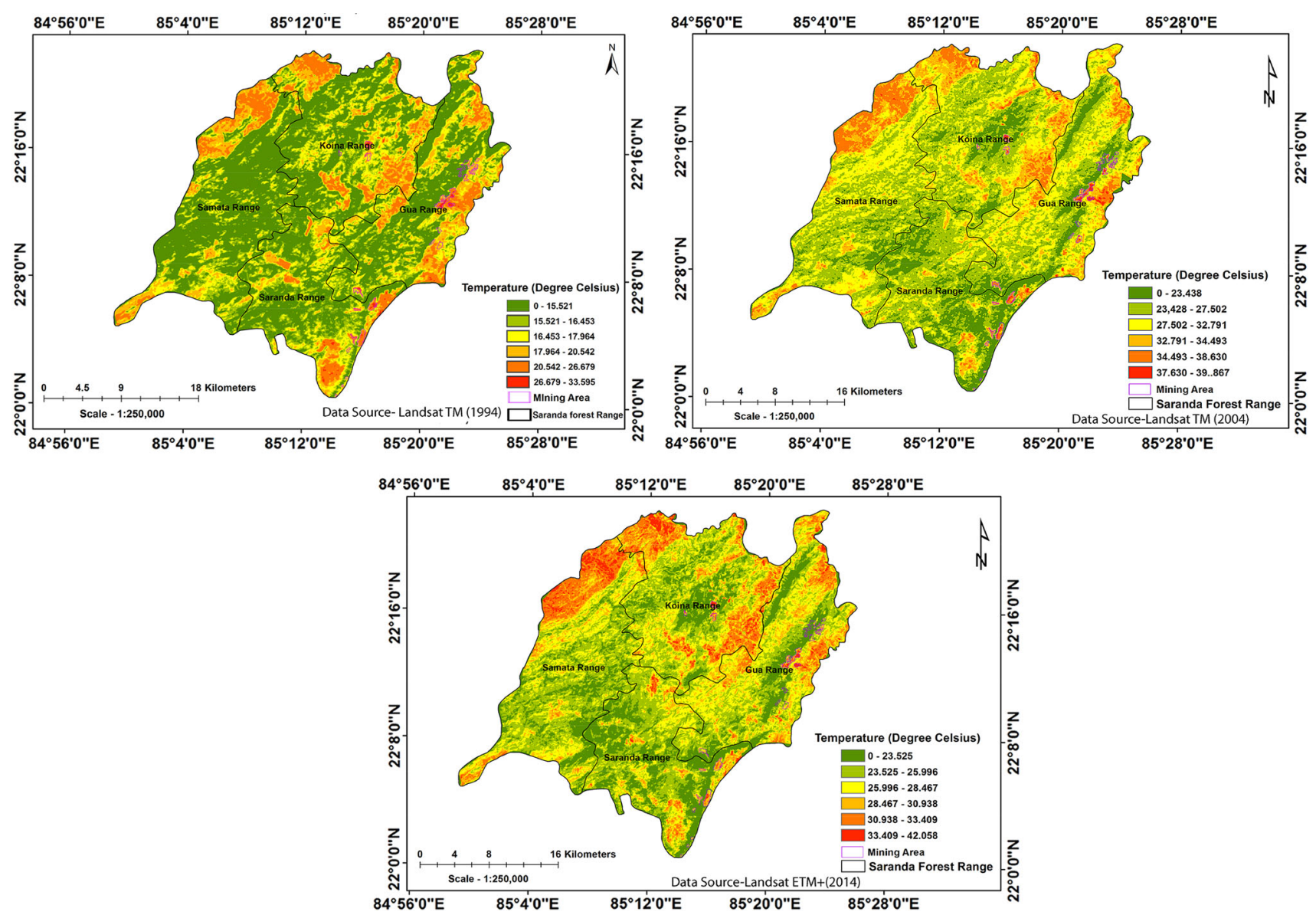

Fig. 3 LST mapping of Saranda forest for years (1994, 2004 and 2014)

Table 2 Calculating the minimum, maximum and average of LST

\begin{tabular}{llll}
\hline Data used with date & Min temperature $\left({ }^{\circ} \mathrm{C}\right)$ & Max temperature $\left({ }^{\circ} \mathrm{C}\right)$ & Average temperature $\left({ }^{\circ} \mathrm{C}\right)$ \\
\hline $\begin{array}{l}\text { Landsat 5 TM } \\
\text { 31 May, 1994 }\end{array}$ & 15.521 & 33.596 & 24.558 \\
Landsat 7 TM & 21.486 & 39.867 & 30.675 \\
10 May, 2004 & & & 32.791 \\
Landsat 7 ETM+ & 23.525 & 42.058 & \\
\hline
\end{tabular}

\begin{tabular}{llll}
\hline Mining dominated region & $\begin{array}{l}\text { Temperature }\left({ }^{\circ} \mathrm{C}\right) \\
(31 \text { May 1994) }\end{array}$ & $\begin{array}{l}\text { Temperature }\left({ }^{\circ} \mathrm{C}\right) \\
(10 \text { May 2004) }\end{array}$ & $\begin{array}{l}\text { Temperature }\left({ }^{\circ} \mathrm{C}\right) \\
(12 / 4 / 2014)\end{array}$ \\
\hline Gua & 32.1 & 38.07 & 42.1 \\
Kiriburu & 28.2 & 34.3 & 37.6 \\
Megataburu & 26.6 & 32.5 & 36.5 \\
Chiria & 27.1 & 29.7 & 34.8 \\
\hline
\end{tabular}

Table 3 Results of LST for each mining site that the land surface temperature has increased over the years in the area where there is more anthropogenic activities occur and for the build-up areas. The study reveals that the north and northwest part exhibits high temperature mainly due to built up (mining area) and 


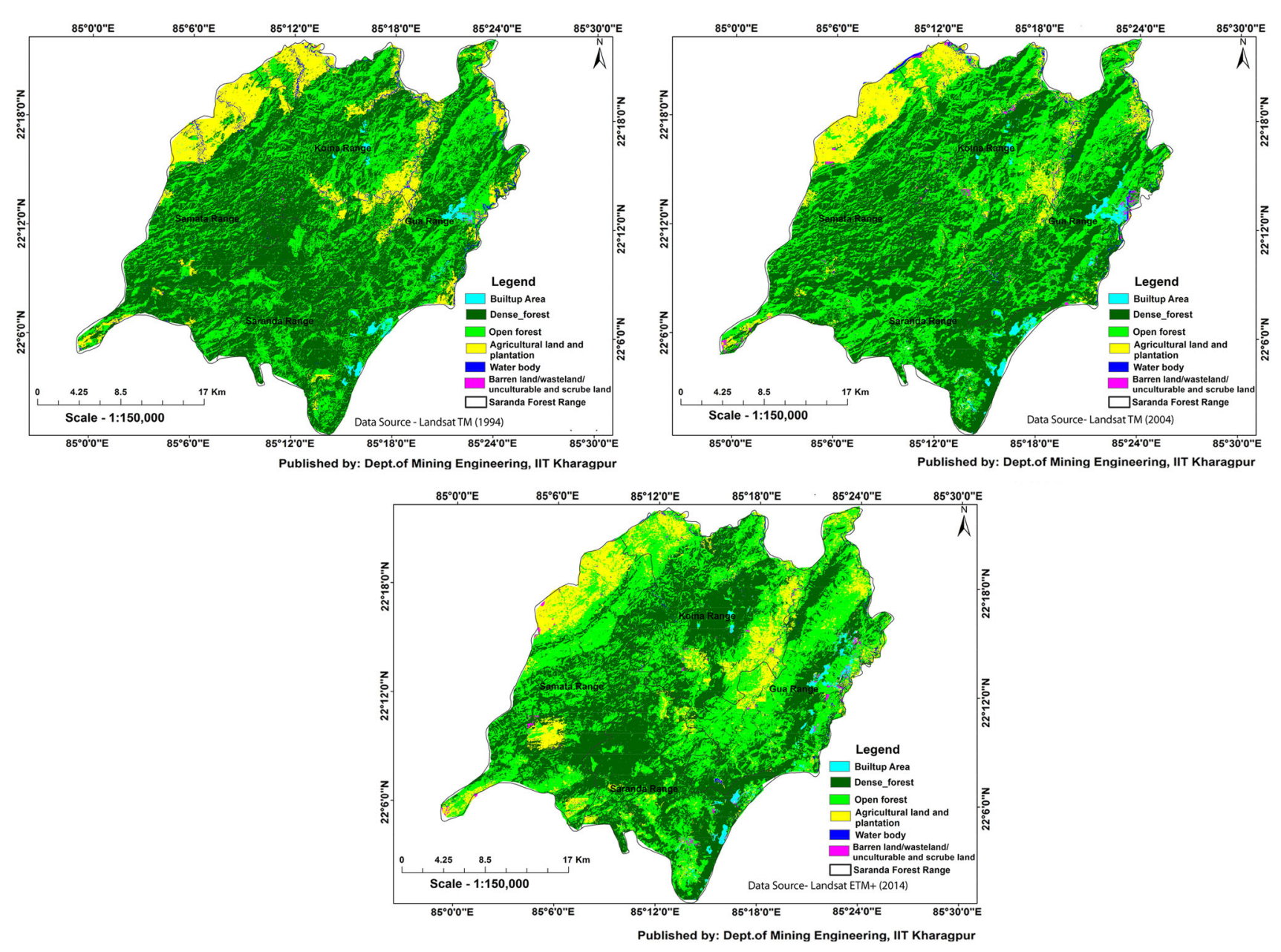

Fig. 4 LULC map of Saranda forest for years (1994, 2004 and 2014)

wetland. Some of the high-temperature zones are also seen in the central part of the image mainly due to anthropogenic land use. The impact of vegetation is clearly perceived as low-temperature values are observed over agricultural cropland, dense vegetation (forest), and sparse vegetation (grass/park) land use categories. It is noted that the land surface temperature has shown a significant increase over the Saranda forest. Assessment of LST provides valuable input for ecological restoration initiatives. For the Saranda forest, it is essential that the rainwater harvesting and wetland development around the iron ore mining belt are necessary. The river line areas and the streams also require periodic maintenance as human activities in the forest area has changed the surface textures, and more areas are prone to erosion and loss of vegetation, which in turn will contribute to surface temperature increase, which could be adverse for the survival of certain critical habitat for ecological balance.

Further investigative studies are necessary to accurately assess the impacts of LST near the hilltop mining areas in particular and for the entire forest region in general. The methodology adopted and presented in this paper for LST mapping provides the necessary information that will help in the environmental management of the mines being operated in the Saranda forest. The natural resource development and administration authorities should use such information to decide initiatives required to combat the impacts of changes in LST. It is the need of the day that the mining companies and to a large extent the forest department and local self-governments must adopt an adequate policy for reclamation and restoration of the areas affected by LST 
Table 4 Results of LST for each LULC categories

\begin{tabular}{|c|c|c|c|c|c|c|}
\hline \multirow[t]{2}{*}{ LU/LC } & \multicolumn{2}{|l|}{31 May, 1994} & \multicolumn{2}{|l|}{10 May, 2004} & \multicolumn{2}{|l|}{1 May, 2014} \\
\hline & Min tem $\left({ }^{\circ} \mathrm{C}\right)$ & Max tem $\left({ }^{\circ} \mathrm{C}\right)$ & Min tem $\left({ }^{\circ} \mathrm{C}\right)$ & Max tem $\left({ }^{\circ} \mathrm{C}\right)$ & Min tem $\left({ }^{\circ} \mathrm{C}\right)$ & Max tem $\left({ }^{\circ} \mathrm{C}\right)$ \\
\hline Built-up & 22.37 & 33.59 & 29.63 & 39.91 & 31.14 & 41.27 \\
\hline Water body & 13.47 & 18.41 & 16.41 & 21.39 & 18.62 & 22.81 \\
\hline Dense forest & 14.56 & 19.78 & 21.66 & 25.27 & 23.92 & 27.47 \\
\hline Open forest & 15.39 & 21.48 & 21.98 & 29.56 & 24.7 & 29.31 \\
\hline Agricultural land & 19.4 & 23.63 & 23.26 & 31.12 & 26.83 & 31.45 \\
\hline Wasted land/wet land & 20.56 & 24.71 & 28.42 & 32.36 & 29.35 & 35.37 \\
\hline
\end{tabular}

Table 5 Error matrix for different LULC classes between 1994, 2004 and 2014

\begin{tabular}{|c|c|c|c|c|c|c|c|c|}
\hline LU/LC classes (1994) & $\begin{array}{l}\text { Dence } \\
\text { forest }\end{array}$ & $\begin{array}{l}\text { Open } \\
\text { forest }\end{array}$ & $\begin{array}{l}\text { Water } \\
\text { body }\end{array}$ & $\begin{array}{l}\text { Agricultural } \\
\text { land }\end{array}$ & $\begin{array}{l}\text { Wet } \\
\text { land }\end{array}$ & $\begin{array}{l}\text { Built up } \\
\text { area }\end{array}$ & Total & $\begin{array}{l}\text { User } \\
\text { accuracy (\%) }\end{array}$ \\
\hline Dence forest & 549835 & 0 & 0 & 0 & 0 & 0 & 549835 & 100 \\
\hline Open forest & 52733 & 334070 & 0 & 0 & 0 & 0 & 386803 & 86.36 \\
\hline Water body & 0 & 0 & 13292 & 0 & 0 & 0 & 13292 & 100 \\
\hline Agricultural land & 0 & 21762 & 0 & 101502 & 0 & 0 & 123264 & 82.34 \\
\hline Wet land & 0 & 0 & 0 & 767 & 2226 & 0 & 2993 & 74.37 \\
\hline Built up area & 0 & 0 & 0 & 2100 & 620 & 9412 & 12132 & 77.57 \\
\hline Total & 602568 & 355832 & 13292 & 104369 & 2846 & 9412 & 1088319 & - \\
\hline Producer accuracy $(\%)$ & 1.24 & 93.88 & 100 & 97.25 & 78.21 & 100 & - & - \\
\hline LU/LC classes $(2004)$ & $\begin{array}{l}\text { Dence } \\
\text { forest }\end{array}$ & $\begin{array}{l}\text { Open } \\
\text { forest }\end{array}$ & $\begin{array}{l}\text { Water } \\
\text { body }\end{array}$ & $\begin{array}{l}\text { Agricultural } \\
\text { land }\end{array}$ & $\begin{array}{l}\text { Wet } \\
\text { land }\end{array}$ & $\begin{array}{l}\text { Built up } \\
\text { area }\end{array}$ & Total & $\begin{array}{l}\text { User } \\
\text { accuracy }(\%)\end{array}$ \\
\hline Dence forest & 473918 & 0 & 0 & 0 & 0 & 0 & 473918 & 100 \\
\hline Open forest & 67623 & 394261 & 0 & 0 & 0 & 0 & 461884 & 85.35 \\
\hline Water body & 0 & 0 & 10827 & 0 & 0 & 0 & 10827 & 100 \\
\hline Agricultural land & 0 & 27713 & 0 & 93392 & 0 & 0 & 115105 & 75.92 \\
\hline Wet land & 0 & 0 & 0 & 1142 & 3369 & 0 & 4511 & 74.68 \\
\hline Built up area & 0 & 0 & 0 & 2129 & 515 & 13430 & 16074 & 83.85 \\
\hline Total & 541541 & 421974 & 10827 & 96663 & 3884 & 13430 & 1088319 & - \\
\hline Producer accuracy $(\%)$ & 87.51 & 93.43 & 100 & 96.61 & 86.74 & 100 & - & - \\
\hline LU/LC classes (2014) & $\begin{array}{l}\text { Dence } \\
\text { forest }\end{array}$ & $\begin{array}{l}\text { Open } \\
\text { forest }\end{array}$ & $\begin{array}{l}\text { Water } \\
\text { body }\end{array}$ & $\begin{array}{l}\text { Agricultural } \\
\text { land }\end{array}$ & Wet land & $\begin{array}{l}\text { Built up } \\
\text { area }\end{array}$ & Total & $\begin{array}{l}\text { User } \\
\text { accuracy (\%) }\end{array}$ \\
\hline Dence forest & 449854 & 0 & 0 & 0 & 0 & 0 & 449854 & 100 \\
\hline Open forest & 69272 & 426329 & 0 & 0 & 0 & 0 & 495601 & 86.02 \\
\hline Water body & 0 & 0 & 9617 & 0 & 0 & 0 & 9617 & 100 \\
\hline Agricultural land & 0 & 32208 & 0 & 74471 & 0 & 0 & 106679 & 69.8 \\
\hline Wet land & 0 & 0 & 0 & 2154 & 4720 & 0 & 6874 & 68.66 \\
\hline Built up area & 0 & 0 & 0 & 2750 & 563 & 16381 & 19694 & 83.17 \\
\hline Total & 519126 & 458537 & 9617 & 79375 & 5283 & 16381 & 1088319 & - \\
\hline Producer accuracy $(\%)$ & 86.65 & 92.97 & 100 & 93.82 & 89.34 & 100 & - & - \\
\hline
\end{tabular}

Bold values indicate number of pixel for which the predicted label is equal to the reference label 


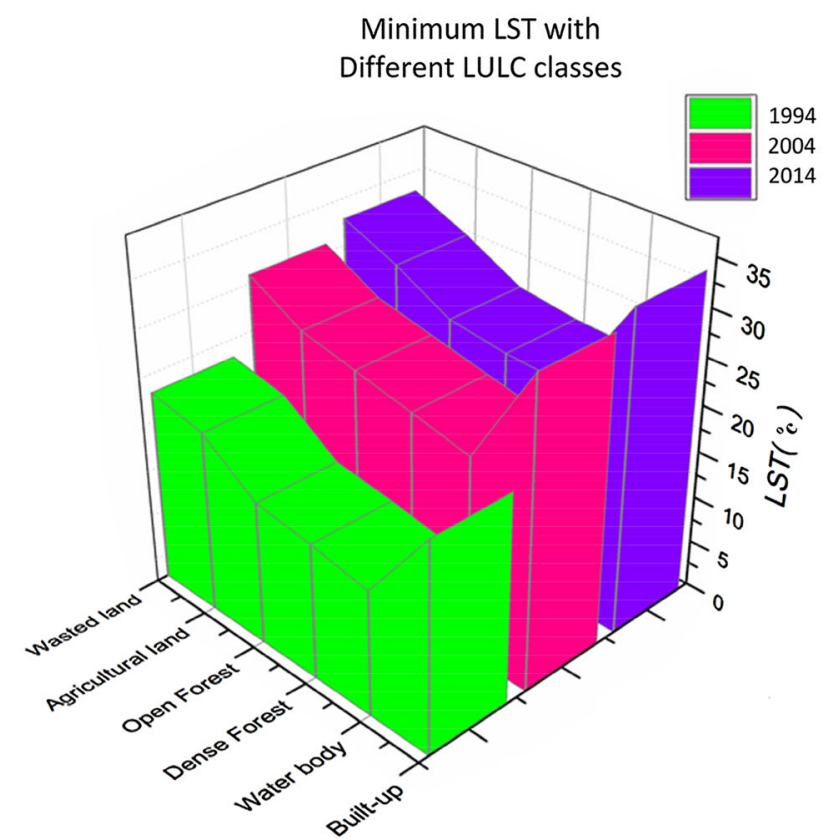

Fig. 5 Increasing trend of LST for the built up areas in Saranda forest

changes due to anthropogenic activities. The methodologies presented in the paper are generic in nature. It can be applied to other regions with suitable modification(s).

Acknowledgments The authors are thankful to SAIL and DFO of Saranda forest for their financial support and providing necessary data. The authors would like to thank Indian Institute of Technology Kharagpur and Vidyasagar University for its constant support and providing wonderful platform for research.

\section{References}

Alavipanah SK, Saradjian M, Savaghebi GR, Komaki CB (2007) Land surface temperature in the Yardang Region of Lut Desert (Iran) based on field measurements and Landsat Thermal Data. J Agric Sci Technol 9:287-303

Amiri R, Weng Q, Alimohammadi A, Alavipanah SK (2009) Spatialtemporal dynamics of land surface temperature in relation to fractional vegetation cover and land use/cover in the Tabriz urban area, Iran. Remote Sens Environ 113(12):2606-2617

Bokaie M, Zarkesh MK, Arasteh PD, Hosseini A (2016) Assessment of Urban Heat Island based on the relationship between land surface temperature and land use/land cover in Tehran. Sustain Cities Soc 23:94-104

Buyadi SNA, Mohd WMNW, Misni A (2013) Impact of land use changes on the surface temperature distribution of area surrounding the National Botanic Garden, Shah Alam. Proc Soc Behav Sci 101:516-525

Cao L, Li P, Zhang L, Chen T (2008) Remote sensing image-based analysis of the relationship between urban heat island and vegetation fraction. Int Arch Photogramm Remote Sens Spatial Inf Sci 37:1379-1384
Maximum LST with Different LULC classes

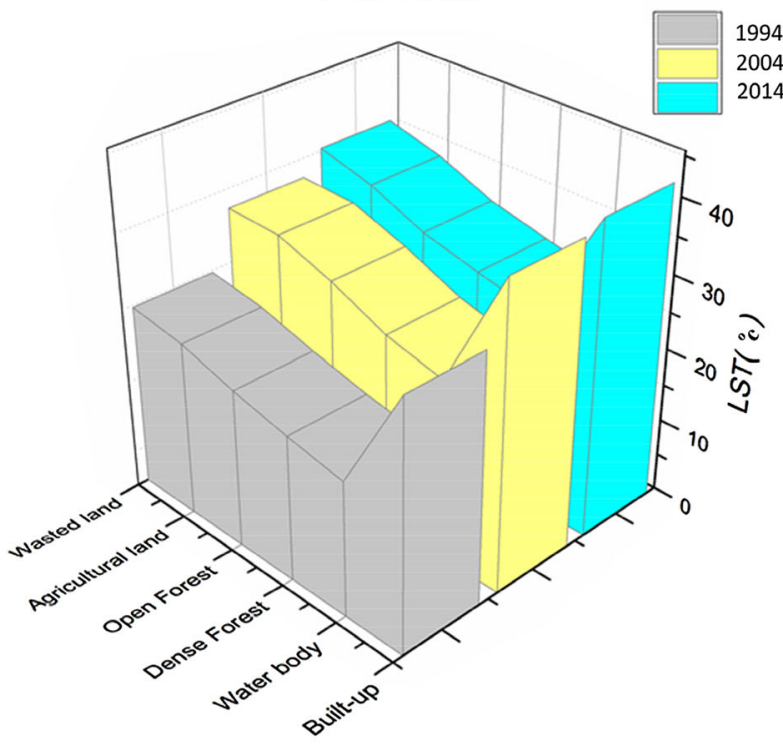

Carlson TN, Arthur ST (2000) The impact of land use-land cover changes due to urbanization on surface microclimate and hydrology: a satellite perspective. Global Planet Change 25(1):49-65

Cristóbal J, Jiménez Muñoz JC, Sobrino JA, Ninyerola M, Pons X (2009) Improvements in land surface temperature retrieval from the Landsat series thermal band using water vapor and air temperature. J Geophys Res Atmos 114:D8

James MM, Mundia CN (2014) Dynamism of land use changes on surface temperature in Kenya: a case study of Nairobi City. Int J Sci Res 3(4):38-41

Kato S, Yamaguchi Y (2005) Analysis of urban heat-island effect using ASTER and ETM+ data: separation of anthropogenic heat discharge and natural heat radiation from sensible heat flux. Remote Sens Environ 99(1):44-54

Kayet N, Pathak K (2015) Remote sensing and GIS based land use/land cover change detection mapping in Saranda Forest, Jharkhand, India. Int Res J Earth Sci 3(10):1-6

Li X, Zhou W, Ouyang Z, Xu W, Zheng H (2012) Spatial pattern of greenspace affects land surface temperature: evidence from the heavily urbanized Beijing metropolitan area, China. Landsc Ecol 27(6):887-898

Lim V, Stubbs JW, Nahar N, Amarasena N, Chaudry ZU, Weng SC et al (2009) Politicians must heed health effects of climate change. Lancet 374(9694):973

Mann ME, Zhang Z, Rutherford S, Bradley RS, Hughes MK, Shindell $\mathrm{D}$, Ni F (2009) Global signatures and dynamical origins of the Little Ice Age and Medieval Climate Anomaly. Science 326(5957):1256-1260

Nichol J (1995) Monitoring tropical rain forest microclimate. Photogram Eng Remote Sens 61:1159-1165

Ragin CC (2014) The comparative method: moving beyond qualitative and quantitativestrategies. University of California Press, Berkeley, CA

Renssen H, Goosse H, Fichefet T, Brovkin V, Driesschaert E, Wolk F (2005) Simulating the Holocene climate evolution at northern high latitudes using a coupled atmosphere-sea ice-ocean-vegetation model. Clim Dyn 24(1):23-43 
Sahoo S (2013) Monitoring urban Land use land cover change by multi-temporal remote sensing information in Howrah City, India. Int Res J Earth Sci 1(5):1-6

Sahoo S, Dhar A, Kar A (2016) Environmental vulnerability assessment using Grey Analytic Hierarchy Process based model. Environ Impact Assess Rev 56:145-154

Schwarz N, Lautenbach S, Seppelt R (2011) Exploring indicators for quantifying surface urban heat islands of European cities with MODIS land surface temperatures. Remote Sens Environ 115(12):3175-3186

Semenza JC, Rubin CH, Falter KH, Selanikio JD, Flanders WD, Howe HL, Wilhelm JL (1995) Heat-related deaths during the July 1995 heat wave in Chicago. N Engl J Med 335(2):84-90

Sobrino N, Raissouni Z Li (2001) A comparative study of land surface emissivity retrieval from NOAA data. Remote Sens Environ 75:256-266

Southworth J (2004) An assessment of Landsat TM band 6 thermal data for analysing land cover in tropical dry forest regions. Int $\mathrm{J}$ Remote Sens 25(4):689-706
USGS (2001) Landsat 7 Science Data User's handbooks

Voogt JA, Oke TR (2003) Thermal remote sensing of urban climates. Remote sensing of

Weng Q (2001) Fractal analysis of satellite-detected urban heat island effect

Weng Q, Lu D, Schubring J (2004) Estimation of land surface temperature-vegetation abundance relationship for urban heat island studies. Remote Sens Environ 89(4):467-483

White-Newsome JL, Brines SJ, Brown DG, Dvonch JT, Gronlund CJ, Zhang K, O'Neill MS (2013) Validating satellite-derived land surface temperature with in situ measurements: a public health perspective. Environ Health Perspect 121(8):925

Zheng B, Myint SW, Fan C (2014) Spatial configuration of anthropogenic land cover impacts on urban warming. Landsc Urban Plann 130:104-111

Zhou W, Huang G, Cadenasso ML (2011) Does spatial configuration matter? Understanding the effects of land cover pattern on land surface temperature in urban landscapes. Landsc Urban Plan 102(1):54-63 